\title{
PENGARUH PENGUNGKAPAN ENTERPRISE RISK MANAGEMENT TERHADAP NILAI PERUSAHAAN DENGAN PROFITABILITAS SEBAGAI VARIABEL MODERASI
}

\author{
Anni Fitriyani Munawwaroh ${ }^{1)}$, Nur Fatoni ${ }^{2)}$, \& Warno ${ }^{3)}$ \\ ${ }^{1}$ Fakultas Ekonomi dan Bisnis Islam, Universitas Islam Negeri Walisongo Semarang \\ email: annifitriyani.mu@gmail.com \\ ${ }^{2}$ Fakultas Ekonomi dan Bisnis Islam, Universitas Islam Negeri Walisongo Semarang \\ email: nurfatoni@walisongo.ac.id \\ ${ }^{3}$ Fakultas Ekonomi dan Bisnis Islam, Universitas Islam Negeri Walisongo Semarang \\ email: warno@walisongo.ac.id
}

\begin{abstract}
This study aims to analyze the influence of Enterprise Risk Management (ERM) on firm value by testing profitability in strengthening or weakening the relationship between Enterprise Risk Management (ERM) and firm value and testing leverage in controlling the relationship between Enterprise Risk Management (ERM) on firm value. in service companies listed on the Indonesian Syari'ah Stock Index (ISSI) 2015 - 2019. The population of this study are service companies listed on the Syari'ah Stock Index (ISSI) 2015 - 2019 as many as 51 companies. The sample selection in this study used a purposive sampling method and 10 companies were selected. Data analysis used the Structural Equation Modeling - Partial Least Square (PLS) method which was run using SmartPLS 3.0 software. The results showed that Enterprise Risk Management (ERM) and Profitability could not affect the Company Value. Profitability cannot strengthen or weaken the relationship between Enterprise Risk Management (ERM) and Company Value. Meanwhile, leverage can control the effect on firm value.
\end{abstract}

Keywords: Enterprise Risk Management, Nilai Perusahaan, Profitabilitas, Leverage

\section{PENDAHULUAN}

Di era globalisasi ini perkembangan ekonomi semakin terintegrasi yang menyebabkan kondisi lingkungan eksternal dan internal dunia ekonomi mengalami perkembangan yang pesat. Dengan adanya kondisi tersebut perusahaan dalam melakukan bisnisnya memiliki keinginan untuk tumbuh dan berkembang dalam mencapai tujuan tujuan yang telah ditetapkan untuk meningkatkan nilai perusahaan. Artinya untuk menuju tujuan tersebut menjadikan perusahaan dalam mengambil keputusan harus selalu memperhitungkan akibatnya terhadap nilai atau harga saham perusahaan. Karena nilai sebuah perusahaan tergambarkan dari harga saham yang diperdagangkan di Bursa Efek Indonesia (BEI) (Achmad Sidiq Pamungkas, 2017).

Pada tahun 2019 pertumbuhan ekonomi Indonesia diukur berdasarkan Produk Domestik Bruto (PDB) atas dasar harga berlaku mencapai $\mathrm{Rp}$ 15.833,9 triliun dan PDB Perkapita mencapai Rp 59,1 Juta atau US\$4.174,9. Ekonomi Indonesia tahun 2019 tumbuh 5,02 persen, lebih rendah dibandingkan capaian tahun 2018 sebesar 5,17 persen. Dari sisi produksi, pertumbuhan tertinggi dicapai Lapangan Usaha Jasa lainnya sebesar 10,55 persen. Data Badan Koordinasi 
Penanaman Modal (BKPM) mencatat realisasi investasi pada sektor perusahaan jasa mengalami kenaikan signifikan dibandingkan perusahaan manufaktur (Muhammad Wildan, 2019). Realisasi tersebut dapat dilihat pada tabel 1 .

Tabel 1. Realisasi Investasi Sektor Manufaktur Vs Jasa

\begin{tabular}{|c|l|c|c|c|}
\hline No & \multicolumn{1}{|c|}{ Sektor } & $\mathbf{2 0 1 7}$ & $\mathbf{2 0 1 8}$ & $\mathbf{2 0 1 9}$ \\
\hline 1. & $\begin{array}{l}\text { Sektor } \\
\text { Manufaktur }\end{array}$ & 274,7 & 222,3 & 147,3 \\
\hline 2. & Sektor Jasa & 293,4 & 367 & 354,5 \\
\hline
\end{tabular}

Sumber: www.idx.co.id

Sejalan dengan Rencana Pembangunan Menengah Nasional (RPJMN) tahun 2015 - 2019 pariwisata menjadi sebuah prioritas, karena menjadi salah satu strategi dari akselerasi pertumbuhan ekonomi nasional. Melalui mekanisme tarikan dan dorongan terhadap sektor ekonomi lain yang terkait dengan sektor pariwasata, seperti hotel, restoran, transportasi dan lain sebagainya. Melalui multiplier effect-nya, pariwisata mampu mempercepat pertumbuhan ekonomi dan penciptaan lapangan kerja yang lebih luas (Universitas Indonesia, 2005). Pada tahun 2019, pemerintah Indonesia menargetkan devisa dari sektor pariwisata sebesar Rp260 triliun selama 5 tahun kedepan. Angka tersebut menurut Menteri Pariwisata 2014 - 2019 sangat wajar, mengingat selama tahun 2014 sektor pariwisata mampu menyumbang devisa sebesar USD10,69 miliar atau setara dengan Rp136 triliun (Harefa, 2020).

Semakin ketatnya pertumbuhan ekonomi Indonesia tersebut membuat perusahaan harus menerapkan strategi untuk memaksimalkan kinerja perusahaan dengan tujuan agar memperoleh laba yang tinggi. Perusahaan harus melakukan perbaikan diri dan mampu berkompetitif untuk meningkatkan kualitas perusahaan yang lebih baik. Selain itu perusahaan juga harus mampu menghadapi risiko risiko dimasa depan yang mengandung ketidakpastian karena setiap bisnis pasti memiliki risiko yang tidak dapat dihindari. Perusahaan yang baik adalah melihat pada nilai perusahaan.

Dengan adanya kinerja perusahaan dapat membangun persepsi investor terhadap perusahaan yang dapat dilihat dari harga sahamnya. Saham merupakan surat berharga yang merepresentasikan penyertaan modal kedalam suatu perusahaan. Sedangkan dalam prinsip syari'ah, penyertaan modal dilakukan pada perusahaan - perusahaan yang tidak melanggar prinsip - prinsip syari'ah, seperti pelarangan bunga (riba'), pelarangan ketidakpastian berlebihan (gharar), larangan spekulasi (maysir) risik kembali, dan larangan berinvestasi di perusahaan yang tidak etis (haram). Dalam melakukan kegiatan investasi, investor yang rasional akan memilih perusahaan yang memiliki kinerja yang baik. Kinerja perusahaan tersebut untuk menilai kemampuan perusahaan dalam memaksimalkan utility pemegang sahamnya.

Kinerja perusahaan yang dapat diukur dengan menganalisa dan mengevaluasi laporan keuangan. Berdasarkan laporan keuangan inilah dapat dihitung sejumlah rasio keuangan yang dijadikan dasar dari penilaian kinerja perusahaan. Rasio keuangan dapat digunakan untuk mengukur tingkat kesehatan, karena rasiorasio tersebut berperan penting dalam evaluasi kinerja perusahaan serta memprediksi kelangsungan usaha baik yang sehat maupun yang tidak sehat. Dalam penelitian ini rasio pengukuran yang digunakan yaitu profitabilitas dan leverage perusahaan. Dari rasio-rasio tersebut dapat menjadi bahan pertimbangan manajemen dalam mengambil suatu kebijakan bagi perusahaan melalui manajemen risiko atau sering disebut dengan Enterprise Risk Management (ERM). 
Penelitian dahulu sudah ada yang meneliti yang berkaitan dengan pengaruh Enterprise Risk Management (ERM) terhadap Nilai Perusahaan, namun penelitian tersebut memiliki hasil yang berbeda - beda. Penelitian yang dilakukan oleh Iswajuni, Soetedjo \& Manasikana di perusahaan manufaktur menemukan bahwa Enterprise Risk Management (ERM) memiliki pengaruh positif terhadap Nilai Perusahaan. Selain itu sama halnya dengan penelitian yang dilakukan oleh Dinoyu \& Septiani juga menemukan hasil bahwa Enterprise Risk Management (ERM) berpengaruh terhadap Nilai Perusahaan dan penelitian yang dilakukan oleh Solikhah \& Hariyati menunjukan hasil yang serupa. Berdasarkan uraian di atas maka peneliti akan melakukan penelitian mengenai Enterprise Risk Management.

\section{KAJIAN LITERATUR DAN PEGEMBANGAN HIPOTESIS Teori Agensi}

Menurut Jensen dan Meckling dalam Mei, Kharis dan Abrar, Teori Agensi adalah teori yang menerangkan tentang hubungan antara pemilik (principal) dan manajer (agent) (Yuniata, Raharjo, and Oemar, 2016). Teori Agensi menyatakan apabila terdapat perbedaan antara pemilik sebagai principal dan manajer sebagai agent dalam menjalankan perusahaan maka akan muncul permasalahan agensi karena masing-masing akan selalu berusaha untuk memaksimalkan fungsi utilitasnya masing-masing (Wijananti, 2013). Teori Agensi ini menjadi suatu landasan dalam pelaksanaan Good Corporate Governance (GCG) berkaitan dengan keberadaan komite yang digunakan untuk mengurangi terjadinya konflik antara pemilik (principal) dengan manajer (agent). Pelaporan dan pengungkapan Enterprise Risk Management (ERM) ini menjadi suatu tanggungjawab manajemen atas prinsip transparansi dalam Good Corporate Governance.

\section{Teori Sinyal}

Teori sinyal adalah suatu teori yang memberikan penekanan kepada perusahaan dalam mengeluarkan sebuah informasi berisi tentang berita baik (good news). Signalling theory ini pasar akan merespon ketika telah menerima informasi good news tersebut dan dapat mempengaruhi pada peningkatan nilai perusahaan. Dalam pengungkapan manajemen dibutuhkan suatu informasi baik itu dari laporan tahunan ataupun laporan keuangan berkaitan dengan pengelolaan perusahaan. Laporan tahunan (annual report) merupakan laporan yang dikeluarkan oleh manajemen perusahaan dalam kurun waktu satu tahun sekali berisi tentang informasi, baik itu finansial ataupun non-finansial perusahaan yang bermanfaat untuk stakeholder dalam mengalisis situasi perusahaan pada periode tersebut (Devi, 2017). Untuk menganalisis kondisi keuangan dari suatu perusahan terdapat laporan keuangan, yang tujuannya untuk menyediakan sebuah informasi posisi keuangan, kinerja keuangan, dan laporan arus kas suatu entitas yang bermanfaat dalam pengambilan keputusan ekonomi oleh siapapun yang membutuhkan laporan keuangan guna memenuhi kebutuhan informasi tertentu (Warno, 2014).

\section{Nilai Perusahaan}

Nilai perusahaan didefinisikan sebagai nilai pasar yang berasal dari suatu ekuitas perusahaan ditambah dengan nilai pasar hutang. Munculnya nilai pasar tersebut karena adanya nilai perusahaan yang memberikan kesejahteraan bagi pemegang saham secara maksimum jika harga saham mengalami peningkatan (Achmad Sidiq Pamungkas 2017). Nilai perusahaan atau dikenal dengan firm value yaitu sebuah konsep yang penting bagi 
investor, pasalnya nilai perusahaan ini menjadi suatu indikator bagi pasar untuk menilai perusahaan secara keseluruhan. Bagi perusahaan yang akan go public nilai perusahaan dapat terlihat berdasarkan dari jumlah variable yang melekat pada perusahaan tersebut seperti aset yang dimiliki perusahaan atau keahlian manajer dalam pengelolaan manajemen risiko perusahaan (Rinnaya, Andini, and Oemar, 2016).

\section{Enterprise Risk Management (ERM)}

Menurut COSO, Enterprise Risk Management adalah suatu proses penentuan strategi perusahaan dalam menjalankan managemen, board of directors, dan personal perusahaan lainnya secara menyeluruh dengan tujuan mengidentifikasi kejadian-kejadian yang berpotensi dapat mempengaruhi dalam pengelolaan risiko dan menyediakan keyakinan yang memenuhi tercapainya tujuan perusahaan (Soetedjo et al. 2018).

Pengungkapan Enterprise Risk Management (ERM) yang tinggi tersebut dapat berdampak positif kepada pandangan pelaku pasar, yang nantinya akan memotivasi pelaku-pasar dalam memberikan harga yang tinggi pada perusahaan sehingga nilai perusahaan juga akan meningkat (Devi, 2017). Enterprise Risk Management (ERM) dapat memberikan nilai tambah kepada perusahaan yang akan memudahkan manajemen untuk mengontrol berbagai macam risiko yang disebabkan kondisi masa depan yang tidak pasti dengan mengintegrasikan semua macam risiko yang muncul menggunakan alat dan teknik terpadu, selanjutnya mengkoordinasikan kegiatan perusahaan tersebut kepada seluruh unit operasi sehingga semua macam risiko dapat diminimalisir oleh manajemen (Soetedjo et al. 2018).

\section{Enterprise Risk Management dalam Pandangan Islam}

Secara umum, Islam memandang risiko sebagai suatu penderitaan yang tidak diinginan hanya ketika mengandung manfaat lebih dari pengganti kerugian yang dihubungkan dengan penderitaan tersebut. Selain itu Islam juga memandang risiko sebagai suatu keberuntungan yang dikaitkan dengan perolehan rizki.(Indrawati et al. 2012) Dalam perspektif Islam managemen risiko merupakan kegiatan dalam menjaga amanah Allah pada harta kekayaan dengan tujuan kemaslahatan manusia. Pengelolaan risiko dapat menghasilkan kemaslahatan yang diartikan sebagai keberhasilan manusia dalam menjaga amanah yang diberikan oleh Allah SWT (Rolianah and Albar, 2019). Kewajiban entitas syari'ah dalam melaksanakan Risk Management sangat diperlukan melihat sangat besarnya persaingan antar perusahaan. Enterprise Risk Management dapat digunakan sebagai gambaran untuk meramalkan apa yang akan terjadi dimasa depan serta dapat pula digunakan sebagai rencana pelaksanaan operasional perusahaan itu sendiri.

\section{Profitabilitas}

Profitabilitas adalah suatu ukuran dari kinerja perusahaan yang ditunjukan dengan hasil laba yang diperoleh perusahaan. Menurut Kasmir profitabilitas merupakan salah satu faktor yang dapat mempengaruhi nilai perusahaan (Wijaya and Sedana, 2015). Profitabilitas sangatlah penting untuk kelangsungan usaha jangka panjang dalam sebuah perusahaan. Perusahaan yang memiliki biaya yang kecil dan laba yang dihasilkan lebih besar disebabkan karena peran manajer yang mampu mengelola perusahaan dengan baik. 


\section{Leverage}

Leverage adalah perhitungan rasio yang berguna untuk mengukur seberapa jauh perusahaan menggunakan hutang (Sutama and Lisa, 2018). Menurut Kasmir leverage merupakan rasio yang digunakan untuk mengukur sejauh mana aktiva perusahaan dibiayai oleh utang (Astriani, 2014). Leverage dapat dipahami sebagai penaksir dari risiko yang melekat pada suatu perusahaan. Artinya leverage yang semakin besar menunjukan risiko investasi yang semakin besar.

\section{Rumusan Hipotesis}

$H_{1}$ : Enterprise Risk Management (ERM) berpengaruh terhadap nilai perusahaan pada perusahaan jasa yang terdaftar di Index Saham Syari'ah Indonesia (ISSI).

$\mathrm{H}_{2}$ : Profitabilitas berpengaruh terhadap nilai perusahaan pada perusahaan jasa yang terdaftar di Index Saham Syari'ah Indonesia (ISSI).

$\mathrm{H}_{3}$ : Profitabilitas mampu memoderasi hubungan antara Enterprise Risk Management dengan nilai perusahaan pada perusahaan jasa yang terdaftar di Index Saham Syari'ah Indonesia (ISSI).

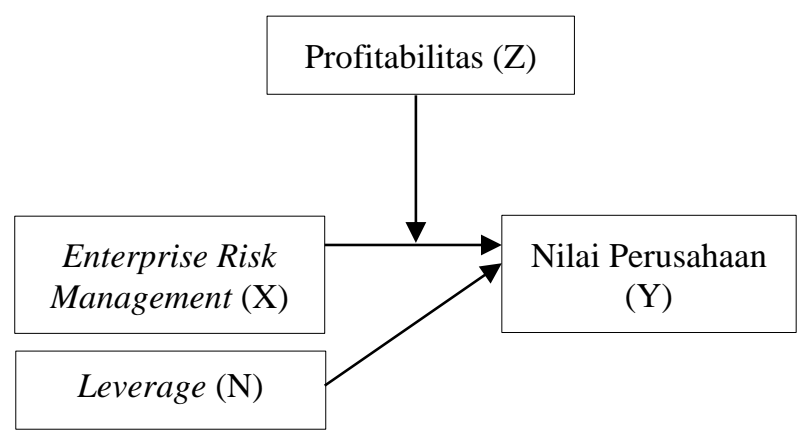

\section{Gambar 1. Kerangka Berpikir}

Keterangan:

$\mathrm{X}$ : Variabel Independen

Y: Variabel Dependen

Z: Variabel Moderasi

$\mathrm{N}$ : Variabel Kontrol

\section{METODE PENELITIAN Jenis dan Sumber Data}

Metode penelitian menggunakan metode penelitian kuantitatif. Penelitian kuantitatif adalah pendekatan yang di dalam usulan penelitian menggunakan aspek pengukuran, perhitungan rumus dan kepastian data numerik (Musianto, 2002). Pendekatan yang digunakan dalam penelitian ini adalah pendekatan Asosiatif. Tujuan pendekatan asosiatif adalah digunakan sebagai alat analisis hubungan antar variable. Penelitian ini dilakukan pada perusahaan jasa yang terdaftar di Index Saham Syari'ah Indonesia (ISSI) tahun 2015 - 2019. Sumber data yang dalam penelitian ini yaitu data sekunder berupa laporan keuangan dan laporan tahunan (annual report) yang diperoleh dari situs resmi Bursa Efek Indonesia (BEI) yaitu www.idx.co.id.

\section{Populasi dan Sampel}

Populasi yang digunakan dalam penelitian ini adalah perusahaan jasa sektor pariwisata, sektor hotel, sektor restoran dan sektor transportasi yang terdaftar di Index Saham Syari'ah Indonesia than 2015 - 2019 dengan total 51 perusahaan. Teknik pengambilan sampel menggunakan metode purposive sampling yaitu berdasarkan kriteria yang telah ditetapkan oleh peneliti. Kriteria untuk sampling pada penelitian ini adalah

1. Perusahaan Jasa Sektor Pariwisata, Hotel, Resto dan Transportasi yang terdaftar di Indeks Saham Syari'ah Indonesia tahun 2015 - 2019.

2. Perusahaan yang terdaftar sebagai saham syari'ah di Indeks Saham Syari'ah tahun 2015 - 2019.

3. Memiliki laporan keuangan dan laporan tahunan (annual report) yang dipublikasikan untuk periode yang berakhir 31 Desember tahun 2015 2019. 
4. Perusahaan yang mengungkapkan Enterprise Risk Management (ERM) di dalam laporan tahunan.

5. Perusahaan yang terhitung pada nilai profitabilitas dan leverage memiliki hasil yang positif.

\section{Teknik Pengumpulan Data}

Tabel 2. Kriteria Pengambilan Sampel

\begin{tabular}{|l|c|}
\hline \multicolumn{1}{|c|}{ Kriteria } & Jumlah \\
\hline $\begin{array}{l}\text { Perusahaan Jasa Sektor Pariwisata, } \\
\text { Hotel, Resto dan Transportasi yang } \\
\text { terdaftar di Indeks Saham Syari'ah } \\
\text { Indonesia tahun 2015 - 2019. }\end{array}$ & 51 \\
\hline $\begin{array}{l}\text { Perusahaan yang terdaftar sebagai } \\
\text { saham syari'ah di Indeks Saham } \\
\text { Syari'ah tahun 2015 - 2019. }\end{array}$ & $(29)$ \\
\hline $\begin{array}{l}\text { Memiliki laporan keuangan dan } \\
\text { laporan tahunan (annual report) } \\
\text { yang dipublikasikan untuk periode }\end{array}$ & $(4)$ \\
$\begin{array}{l}\text { yang berakhir 31 Desember tahun } \\
\text { 2015 - 2019. }\end{array}$ & \\
\hline $\begin{array}{l}\text { Perusahaan melakukan } \\
\text { pengungkapan Enterprise Risk } \\
\text { Management dalam laporan } \\
\text { tahunan. }\end{array}$ & $(0)$ \\
\hline $\begin{array}{l}\text { Perusahaan yang memiliki nilai } \\
\text { profitabilitas dan leverage positif. }\end{array}$ & $(8)$ \\
\hline Perusahaan yang masuk kriteria & $\mathbf{1 0}$ \\
\hline $\begin{array}{l}\text { Total Perusahaan yang menjadi } \\
\text { sampel penelitian 10x 5 tahun }\end{array}$ & $\mathbf{5 0}$ \\
\hline
\end{tabular}

Sumber: Data Sekunder Diolah

\section{Definisi Operasional Variabel Penelitian \\ Nilai Perusahaan}

Variabel dependen yang digunakan yaitu Nilai Perusahaan. Variabel ini diukur menggunakan rasio Price to Book Value (PBV). Price Book Value (PBV) merupakan perhitungan atau perbandingan antara market value dengan book value suatu saham. Rasio ini menggambarkan potensi pergerakan harga suatu saham sehingga dari gambaran tersebut secara tidak langsung rasio PBV ini juga memberikan pengaruh terhadap harga saham.

$$
P B V=\frac{\text { Market Price per Share }(M P S)}{\text { Book Value per Share }(B V S)}
$$

\section{Enterprise Risk Management (ERM)}

Variabel Independen yang digunakan pada penelitian ini adalah Enterprise Risk Management (ERM). Variabel ini diukur menggunakan Enterprise Risk Management (ERM) Framework yang diterbitkan oleh COSO, ada 108 item pengungkapan ERM yang meliputi delapan dimensi diantaranya yaitu lingkungan internal, penetapan tujuan, identifikasi kejadian, penilaian risiko, respon atas risiko, kegiatan pengawasan, informasi dan komunikasi serta pemantauan. Perhitungan item - item tersebut menggunakan pendekatan dummy yaitu setiap item ERM yang diungkapkan diberi nilai dan apabila tidak diungkapkan diberi 0 .

$$
E R M=\frac{\text { Total Item yang Diungkapkan }}{\text { Total Item Pengungkapan }}
$$

\section{Profitabilitas}

Variabel moderasi yang digunakan pada penelitian ini adalah Profitabilitas. Variabel ini diukur menggunakan Return on Asset (ROA). ROA menunjukan kapasitas perusahaan dalam menghasilkan laba menggunakan seluruh aktiva yang dimiliki perusahaan. ROA adalah pengukuran antara laba bersih terhadap jumlah aset.

$$
R O A=\frac{\text { Laba Bersih }}{\text { Total Aset }} \times 100 \%
$$

\section{Leverage}

Variabel kontrol yang digunakan pada penelitian ini adalah Leverage. Variabel ini diukur menggunakan rasio Debt to Equity Ratio (DER). DER merupakan rasio yang menunjukan sejauh mana total modal sendiri perusahaan menjamin seluruh hutang (Nukmaningtyas and Worokinasih, 2018) 
DER $=\frac{\text { Total Debt }}{\text { Total Equity }} \times 100 \%$

\section{HASIL}

\section{Uji Model Pengukuran (Outer Model)}

1. Convergent Validity: Model pengukuran dengan convergent validity digunakan untuk menguji validitas yang dapat dilihat dari indicator yang dinilai berdasarkan korelasi antara item score component score.

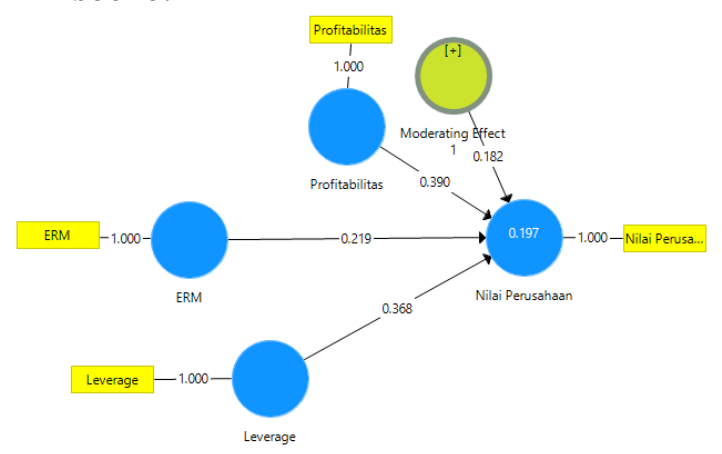

Gambar 1. Model Struktur dengan Partial Least Square

Tabel 3. Combine Loading

\begin{tabular}{|l|c|c|c|c|c|l|}
\hline & ERM & DER & $\begin{array}{l}\text { ROA* } \\
\text { ERM }\end{array}$ & PBV & ROA & $\begin{array}{l}\text { Type (as } \\
\text { defined) }\end{array}$ \\
\hline $\begin{array}{l}\text { ROA* } \\
\text { ERM }\end{array}$ & 0,000 & 0,000 & 1,360 & 0,000 & 0,000 & Reflective \\
\hline DER & 0,000 & 1,000 & 0,000 & 0,000 & 0,000 & Reflective \\
\hline PBV & 0,000 & 0,000 & 0,000 & 1,000 & 0,000 & Reflective \\
\hline ROA & 0,000 & 0,000 & 0,000 & 0,000 & 1,000 & Reflective \\
\hline ERM & 1,000 & 0,000 & 0,000 & 0,000 & 0,000 & Reflective \\
\hline
\end{tabular}

Sumber: Pengolahan Data dengan PLS, 2021

Berdasarkan gambar dan tabel diatas, terlihat bahwa nilai outer loading dari indicator ERM, Nilai Perusahaan, Profitabilitas dan Leverage menghasilkan angka 1,00. Hal tersebut menunjukan bahwa nilai pada setiap indicator memiliki nilai berada di atas 0,7 . Oleh karena itu kriteria pada indicator convergent validity terpenuhi.

2. Discriminant Validity: Untuk menguji nilai Discriminant Validity adalah dengan menilai Average Variance Extracted (AVE). Konstruk dikatakan memiliki reliabilitas yang tinggi jika nilainya 0,70 dan AVE berada diatas 0,50 .

Tabel 4. Average Variance Extracted

\begin{tabular}{|l|c|r|c|}
\hline \multicolumn{1}{|c|}{ Variabel } & AVE & $\begin{array}{c}\text { AVE yang } \\
\text { disyaratkan }\end{array}$ & Ket. \\
\hline ERM & 1,000 & 0,50 & Valid \\
\hline DER & 1,000 & 0,50 & Valid \\
\hline ROA*ERM & 1,000 & 0,50 & Valid \\
\hline PBV & 1,000 & 0,50 & Valid \\
\hline ROA & 1,000 & 0,50 & Valid \\
\hline
\end{tabular}

Sumber: Pengolahan Data dengan PLS, 2021

Pada tabel 4 menunjukan nilai AVE untuk seluruh variabel di atas 0,50 sehingga dapat disimpulkan bahwa masing-masing konstruk valid yang artinya indicator yang dipakai telah memenuhi kriteria convergent validity dan discriminant validity menunjukan bahwa semua kriteria terpenuhi sehingga semua instrument yang digunakan dalam penelitian ini lolos dari uji validitas.

3. Composite Reability: Untuk mengukur nilai reliabilitas yaitu dengan cara melihat pada composite reliability dan Cronbach Alpha dari blok indikator yang mengukur kontruk. Kontruk dinyatakan reliabel apabila nilai composite reliability di atas 0,70 dan cornbach alpha di atas 0,70 .

Tabel 5. Nilai Composite Reliability dan Cronbach Alpha

\begin{tabular}{|l|l|r|r|r|l|}
\hline Variabel & CR & $\begin{array}{l}\text { CR yang } \\
\text { Disyarat } \\
\text {-kan }\end{array}$ & CA & $\begin{array}{l}\text { CA yang } \\
\text { Disyarat } \\
\text {-kan }\end{array}$ & Ket. \\
\hline ERM & 1,000 & 0,70 & 1,000 & 0,70 & Reliabel \\
\hline DER & 1,000 & 0,70 & 1,000 & 0,70 & Reliabel \\
\hline PBV & 1,000 & 0,70 & 1,000 & 0,70 & Reliabel \\
\hline ROA & 1,000 & 0,70 & 1,000 & 0,70 & Reliabel \\
\hline $\begin{array}{l}\text { ROA* } \\
\text { ERM }\end{array}$ & 1,000 & 0,70 & 1,000 & 0,70 & Reliabel \\
\hline
\end{tabular}

Sumber: Pengolahan Data dengan PLS, 2021

Berdasarkan data di atas menunjukan hasil analisis dari indikator ERM, Leverage, Nilai Perusahaan, Profitabilitas 
dan Moderating Effect (ERM*Profitabilitas) untuk masing masing menghasilkan angka 1 . Artinya dari hasil pengujian diatas diketahui bahwa pada semua indikator penelitian ini ikut terseleksi oleh batas outer loading.

\section{Uji Evaluasi Inner Model}

Model Struktural adalah model yang mendeskripsikan hubungan antar kontruk (variabel laten) (Azuar Juliandi, 2018). Model struktural dievaluasi dengan menggunakan $R$-square.

Tabel 6. R-Square

\begin{tabular}{|l|l|}
\hline Variabel & R-Square \\
\hline ROA*ERM & - \\
\hline DER & - \\
\hline PBV & 0,197 \\
\hline ROA & - \\
\hline ERM & - \\
\hline
\end{tabular}

Sumber: Pengolahan Data dengan PLS, 2021

Untuk menguji inner model dapat dilakukan dengan melihat nilai $Q^{2}$ (Predictive Relevance). Nilai $Q^{2}$ untuk Nilai Perusahaan diperoleh dengan cara sebagai berikut:

$Q^{2}=1-\left(1-R^{2}\right)$

$Q^{2}=1-\left(1-0,197^{2}\right)$

$Q^{2}=1-(1-0,038809)$

$Q^{2}=1-0,961191$

$Q^{2}=0,038809$

Dari perhitungan diatas menunjukan bahwa nilai $Q^{2}>0$ dimana $0,038809>0$, sehingga Moderating Effect, Leverage, Profitabilitas dan ERM memiliki predictive relevance terhadap Nilai Perushaan yang baik dengan nilai $>0$ yaitu 0,038809 .

\section{Uji Hipotesis}

Pengujian hipotesis dilakukan dengan melihat pada $p$-value.
Tabel 7. Hipotesis Penelitian

\begin{tabular}{|l|c|l|l|}
\hline & P Value & Kriteria & Hipotesis \\
\hline $\begin{array}{l}\text { ERM* } \\
\text { PBV }\end{array}$ & 0,069 & P $<0,05$ & Ditolak \\
\hline $\begin{array}{l}\text { ROA* } \\
\text { PBV }\end{array}$ & 0,280 & P $<0,05$ & Ditolak \\
\hline $\begin{array}{l}\text { ROA* } \\
\text { ERM* } \\
\text { PBV }\end{array}$ & 0,253 & P $<0,05$ & Ditolak \\
\hline
\end{tabular}

Sumber: Pengolahan Data dengan PLS, 2021

\section{PEMBAHASAN}

Pengaruh Enterprise Risk Management terhadap Nilai Perusahaan

Berdasarkan hasil perhitungan statistik menunjukan p-value pada variabel Enterprise Risk Management adalah sebesar 0,069. Maka nilai $p$-value tersebut lebih besar dari tingkat signifikansi 0,05. Variabel ERM memiliki pengaruh yang positif terhadap nilai perusahaan sebesar 0,219 yang berarti apabila nilai ERM meningkat sebesar satu satuan maka nilai perusahaan akan meningkat sebesar 21,9\%. Adapun sebaliknya, apabila terjadi penurunan penilaian terhadap ERM sebesar satu satuan, maka penilaian terhadap nilai perusahaan akan menurun sebesar $21,9 \%$. Dan pada besaran pengaruh ERM terhadap Nilai Perusahaan yaitu sebesar 0,052, yang berarti variable Enterprise Risk Management (ERM) mempengaruhi nilai perusahaan sebesar $5,2 \%$. Hal tersebut menunjukan pengaruh ERM terhadap nilai perusahaan masih tergolong sangat kecil. Sedangkan selebihnya dipengaruhi oleh variable lain dari luar penelitian. Sehingga dapat disimpulkan bahwa Enterprise Risk Management (ERM) tidak berpengaruh terhadap nilai perusahaan atau hipotesis pertama ditolak.

Penelitian ini sejalan dengan penelitian yang dilakukan oleh (Arifah and Wirajaya 2018) dan (Ardianto and Rivandi 2018) yang menyatakan bahwa Enterprise Risk Management (ERM) tidak memiliki pengaruh terhadap Nilai Perusahaan. Namun penelitian ini tidak 
sejalan dengan penelitian yang dilakukan oleh (Soetedjo et al. 2018) begitupula dengan penelitian yang dilakukan oleh (Rachmatus Solikhah and Hariyati 2019) yang menyatakan bahwa Enterprise Risk Management (ERM) berpengaruh terhadap nilai perusahaan.

Berdasarkan teori agensi dalam menjalankan operasional perusahaan, manajer mengoperasikan perusahaan sesuai dengan kepentingan para stakeholder begitupun dalam pengambilan keputusan oleh manajer harus disesuaikan dengan kepentingan stakeholder salah satunya investor melalui pengawasan Enterprise Risk Management. ERM bagi investor adalah suatu hal yang penting sebagai sinyal informasi yang berkenaan dengan keamanan dana yang diinvestasikan oleh investor. Dari hasil penelitian ini menunjukan bahwa Enterprise Risk Management tidak mempunyai pengaruh yang kuat terhadap peningkatan nilai perusahaan, dimana penerapan ERM masih terbatas pada tingkat initiation dan involving sehingga investor tidak melihat informasi mengenai manajemen risiko secara keseluruhan dalam pengambilan keputusan.

Hubungan yang tidak berpengaruh ini menggambarkan bahwa perusahaan masih memerlukan informasi yang akurat dan kuat yang akan diberikan kepada stakeholder berkaitan dengan pengelolaan risiko yang disajikan dalam laporan tahunan perusahaan. Kurangnya informasi mengenai pengelolaan risiko menjadikan investor di Indonesia belum bisa menangkap pengungkapan risiko sebagai sinyal yang baik (good news) sehingga tidak bisa meningkatkan persepsi pasar untuk mendorong nilai perusahaan.

\section{Pengaruh Profitabilitas terhadap Nilai Perusahaan}

Berdasarkan hasil perhitungan statistik nilai $p$-value pada variabel
Profitabilitas yang diproksikan menggunakan Return on Asset (ROA) adalah sebesar 0,280 yang artinya hasil tersebut tidak sesuai dengan tingkat signifikansi karena lebih dari 0,05. Variabel Profitabilitas memiliki pengaruh yang positif terhadap nilai perusahaan yang dilihat pada nilai koefisien beta sebesar 0,390. Hasil tersebut menunjukan apabila nilai Profitabilitas yang diukur dengan ROA tersebut meningkat sebesar satu satuan maka nilai perusahaan akan meningkat sebesar 39\%. Adapun sebaliknya, apabila terjadi penurunan penilaian terhadap Profitabilitas sebesar satu satuan, maka penilaian terhadap nilai perusahaan yang diukur dengan Price Book Value (PBV) akan menurun sebesar $39 \%$. Selain itu besarnya pengaruh Profitabilitas terhadap1nilai perusahaan dapat dilihat pada total effect sebesar 0,087 yang artinya variable Profitabilitas mempengaruhi nilai perusahaan sebesar $8,7 \%$. Dari hasil tersebut menunjukan pengaruh Profitabilitas terhadap nilai perusahaan masih tergolong sangat kecil. Sedangkan selebihnya dipengaruhi oleh variabel lain dari luar penelitian. Dapat disimpulkan dari hipotesis kedua yang menyatakan Profitabilitas berpengaruh terhadap nilai perusahaan tidak dapat diterima. Berdasarkan hasil penelitian berarti Profitabilitas tidak berpengaruh terhadap Nilai Perusahaan.

Hasil penelitian ini sejalan dengan penelitian yang dilakukan oleh (Zuraida, 2019) dan (Untu et al. 2016) menerangkan bahwa profitabilitas tidak berpengaruh terhadap nilai perusahaan. Akan tetapi tidak sejalan dengan penelitian yang dilakukan oleh (Gultom and Wijaya, 2014) yang melakukan penelitiannya di Perusahaan Farmasi yang menyatakan bahwa profitabilitas berpengaruh terhadap nilai perusahaan. Mereka berpendapat bahwa laba bersih yang berada di Perusahaan Farmasi memiliki laba yang tinggi yang dapat meminimalkan beban 
perusahaan dan memaksimalkan laba perusahaan sehingga dapat meningkatkan nilai perusahaan dan menjadikan investor tertarik untuk menanamkan sahamnya pada perusahaan Farmasi tersebut. Hal serupa pada penelitian yang dilakukan oleh (Rinnaya et al. 2016) yang melakukan penelitiannya pada Perusahaan Manufaktur.

Profitabilitas ini merupakan sinyal bagi manajemen dalam mengukur dan mengelola risiko dimasa depan. Akan tetapi pada penelitian ini besar pengaruh laba yang ada di perusahaan jasa tidak bisa meningkatkan nilai perusahaan. Apabila profitabilitas mengalami peningkatan keuntungan, perusahaan menggunakan keuntungan tersebut untuk laba ditahan dan tidak dibagikan kepada pemegang saham, maka hal tersebut tidak bisa dikatakan baik untuk kelangsungan perusahaan dan menjadikan investor menganggap hal tersebut adalah sinyal yang negative yang dapat menurunkan nilai perusahaan.

\section{Pengaruh Moderasi Profitabilitas terhadap Enterprise Risk Management dan Nilai Perusahaan}

Berdasarkan hasil perhitungan statistik di atas diketahui bahwa Variabel Profitabilitas dalam memoderasi hubungan antara Enterprise Risk Management (ERM) dengan Nilai Perusahaan memiliki nilai $p$-value yang menunjukan angka 0,253, yang artinya nilai tersebut lebih dari nilai batas signifikan 0,05. Adapun variabel profitabilitas dalam memoderasi ERM dengan Nilai Perusahaan memiliki pengaruh yang dilihat pada nilai koefisien beta sebesar 0,182. Adapun besarnya pengaruh Profitabilitas terhadap nilai perusahaan dapat dilihat pada total effect sebesar 0,034 yang berarti variable Profitabilitas mempengaruhi nilai perusahaan sebesar 3,4\% artinya pengaruh profitabilitas tidak dapat memoderasi hubungan antara ERM terhadap Nilai Perusahaan karena hasil dari penelitian ini sangat kecil. Sehingga dapat disimpulkan bahwa Profitabilitas dapat memoderasi hubungan antara Enterprise Risk Management (ERM) dengan Nilai Perusahaan tidak dapat memoderasi hubungan antara keduanya atau pada hipotesis ketiga tidak diterima.

Hasil penelitian ini sejalan dengan penelitian yang dilakukan oleh (Desy Mariani, 2018) yang menyatakan bahwa profitabilitas tidak dapat memoderasikan pengaruh antara Enterprise Risk Management (ERM) terhadap nilai perusahaan. Mereka berpendapat bahwa ketika perusahaan mengungkapkan manajemen terhadap risiko - risiko semakin luas maka yang mungkin ataupun telah terjadi di suatu perusahaan tidak dapat mempengaruhi nilai perusahaan baik pada saat perusahaan tersebut mendapatkan profit yang tinggi ataupun rendah. Berbeda dengan penelitian yang dilakukan oleh (Sari, 2020) yang menyatakan bahwa profitabilitas dapat memoderasikan pengaruh antara Enterprise Risk Management (ERM) terhadap Nilai Perusahaan.

Profitabilitas merupakan informasi finansial perusahaan yang menggambarkan kinerja manajemen dalam mengelola perusahaan. Akan tetapi tinggi rendahya profitabilitas yang dimiliki perusahaan tidak dapat mempengaruhi terhadap pengungkapan manajemen risiko yang dihadapi oleh perusahaan sehingga informasi yang terdapat dalam profitabilitas tidak dapat mewakili adanya pengelolaan risiko di masa yang akan datang dalam meningkatkan nilai pasar dimata investor.

\section{Pengaruh Leverage terhadap Nilai Perusahaan sebagai Variabel Kontrol}

Berdasarkan hasil perhitungan statistik menggunakan PLS variabel leverage memiliki nilai $p$-value sebesar 
0,010 yang artinya nilai tersebut lebih rendah dari nilai signifikani 0,05 . Variabel leverage yang diukur dengan Debt of Equaty Ratio (DER) ini sebagai variabel kontrol juga memiliki pengaruh yang positif yang dilihat dari nilai koefisien beta sebesar 0,368. Dari hasil pengujian tersebut menunjukan bahwa terdapat pengaruh leverage terhadap nilai perusahaan.

Hal ini sejalan dengan penelitian yang dilakukan oleh (Devi, 2017) yang mana leverage sebagai variabel kontrol dapat berpengaruh terhadap nilai perusahaan. Hal serupa dengan penelitian yang dilakukan oleh (Aditya and Naomi, 2017) di sektor jasa konstruk properti dimana leverage memiliki pengaruh yang positif dan signifikan terhadap nilai perusahaan. Dengan adanya penggunaan leverage tersebut dapat meningkatkan tingkat produksi sehingga perusahaan memperoleh keuntungan yang lebih besar maka nilai perusahaan ikut meningkat. Besarnya kewajiban beban bunga yang harus dibayarkan perusahaan justru akan meningkatkan semangat investor dalam menaruh sahamnya pada perusahaan tersebut.

Namun berbeda halnya dengan penelitian yang dilakukan oleh (Sanjaya and Linawati, 2015) yang menyatakan bahwa leverage memiliki pengaruh negatif signifikan yang artinya dengan adanya hutang yang tinggi maka akan mengakibatkan turunnya nilai perusahaan sehingga akan memperbesar risiko yang dihadapi dan semakin besar kewajiban untuk membayar beban bunga.

\section{SIMPULAN, IMPLIKASI, DAN KETERBATASAN}

Hasil uji hipotesis pertama menunjukan bahwa Enterprise Risk Manajement tidak berpengaruh terhadap nilai perusahaan. Dari hasil penelitian ini menunjukan bahwa Enterprise Risk Management tidak mempunyai pengaruh yang kuat terhadap peningkatan nilai perusahaan, dimana penerapan ERM masih terbatas pada tingkat initiation dan involving sehingga investor tidak melihat informasi mengenai manajemen risiko secara keseluruhan dalam pengambilan keputusan. Hal ini berarti Investor tidak bisa menangkap sinyal yang baik di perusahaan jasa sektor pariwisata, hotel, resto dan transportasi sehingga tingkat kepercayaan dan kepastian bagi stakeholder khususnya investor menjadi rendah.

Hasil uji hipotesis kedua menunjukan bahwa Profitabilitas tidak berpengaruh terhadap nilai perusahaan. Pengaruh laba yang ada di perusahaan jasa tidak bisa meningkatkan nilai perusahaan. Apabila profitabilitas mengalami peningkatan keuntungan, perusahaan menggunakan keuntungan tersebut untuk laba ditahan dan tidak dibagikan kepada pemegang saham, maka hal tersebut tidak bisa dikatakan baik untuk kelangsungan perusahaan dan menjadikan investor menganggap hal tersebut adalah sinyal yang negatif yang dapat menurunkan nilai perusahaan. Hal ini berarti semakin rendahnya nilai keuntungan perusahaan jasa maka prospek perusahaan dimasa yang akan datang semakin rendah pula dan akan mempengaruhi harga saham yang semakin menurun.

Hasil uji hipotesis ketiga menunjukan bahwa profitabilitas tidak mampu memoderasi hubungan antara Enterprise Risk Manajement dengan Nilai Perusahaan. Hal ini berarti tinggi rendahnya nilai profitabilitas tidak dapat memperkuat informasi yang akan disampaikan dalam pengungkapan ERM melalui nilai perusahaan kepada para stakeholder. 


\section{REFERENSI}

Achmad Sidiq Pamungkas, Sri Maryati. 2017. "Pengaruh Enterprise Risk Mananagement Disclosure, Intellectual Capital Disclosure Dan Debt to Aset Ratio Terhadap Nilai Perusahaan." P. hlm. 412 in SENAS IBB DARAJAYA.

Aditya, Oka, and Prima Naomi. 2017. "Penerapan Manajemen Risiko Perusahaan Dan Nilai Perusahaan Di Sektor Konstruksi Dan Properti." Jurnal Bisnis Dan Manajemen 7(2):hlm. 176-177. doi: 10.15408/ess.v7i2.4981.

Ardianto, Dedi, and Muhammad Rivandi. 2018. "Pengaruh Enterprise Risk Management Disclosure, Intellectual Capital Disclosure Dan Struktur Pengelolaan Terhadap Nilai Perusahaan." Jurnal Profita 11(2):284. doi: 10.22441/profita.2018.v11.02.009.

Arifah, Elli, and I. Gede Ary Wirajaya. 2018. "Pengaruh Pengungkapan Enterprise Risk Management Terhadap Nilai Perusahaan Dengan Ukuran Perusahaan, Leverage, Dan Profitabilitas Sebagai Variabel Kontrol." E-Jurnal Akuntansi 25(2):hlm. $1616 . \quad$ doi: 10.24843/eja.2018.v25.i02.p30.

Astriani, Eno Fuji. 2014. "Pengaruh Kepemilikan Manajerial, Leverage, Profitabilitas, Ukuran Perusahaan Dan Investment Opportunity Set Terhadap Nilai Perusahaan Studi Pada Perusahaan Manufaktur Yang Terdaftar Di Bursa Efek Indonesia Tahun 2009-2011."

Desy Mariani, Suryani. 2018. "Pengaruh Enterprise Risk Management Disclosure, Intellectual Capital Disclosure Dan Corporate Social Responsibility Disclosure Terhadap Nilai Perusahaan Nilai Perusahaaan Dengan Profitabilitas Sebagai
Variabel Pemoderasi (Studi Empiris Pada Perusahaan Sek." Jurnal Akuntansi Dan Keuangan FEB Universitas Budi Luhur 7(2):hlm. 122.

Devi, Sunitha. 2017. "Pengaruh Pengungkapan Enterprise Risk Management Dan Pengungkapan Interllectual Capital Terhadap Nilai Perusahaan." Jurnal Akuntansi Dan Keuangan Indonesia 14(1):hlm. 26.

Gultom, Robinhot, and Sri Widia Wijaya. 2014. "Analisis Faktor Faktor Yang Mempengaruhi Nilai Perusahaan Farmasi Di Bursa Efek Indonesia Periode 2008-2011." Jurnal Wira Ekonomi Mikroskil 3(1):51-60.

Harefa, Mandala. 2020. "Dampak Sektor Pariwisata Terhadap Penerimaan Daerah Di Kabupaten Belitung." Jurnal Ekonomi \& Kebijakan Publik 11(1):hlm. 66.

Indonesia, Lembaga Penyelidikan Ekonomi dan Masyarakat Fakultas Ekonomi dan Bisnis Universitas. 2005. "Laporan Akhir Kajian Dampak Sektor Pariwisata Terhadap Perekonomian Indonesia." hlm. 3.

Indrawati, Nur Khusniyah, Ubud Salim, Djumilah Hadiwidjojo, and Nur Syam. 2012. "Manajemen Risiko Berbasis Spiritual Islam." EKUITAS (Jurnal Ekonomi Dan Keuangan) 16(2):hlm. 184 . doi: 10.24034/j25485024.y2012.v16.i2.2 325.

Juliandi, Azuar, and Disampaikan Pelatihan. 2018. Structural Equation Model Partial Least Square (SEMPLS) Dengan SmartPLS.

Nukmaningtyas, Firasari, and Saparila Worokinasih. 2018. "Penggunaan Rasio Profitabilitas, Likuiditas, Leverage Dan Arus Kas Untuk Memprediksi Financial Distress Pada Perusahaan Sektor Aneka Industri Di BEI." Jurnal Administrasi Bisnis 61(2):hlm. 139. 
Profitabilitas, Pengaruh, Keputusan Investasi Dan, Farmasi Yang, Terdaftar Di, B. E. I. Periode, Jurusan Manajemen, Fakultas Ekonomi, and Universitas Sam Ratulangi. 2016. "Pengaruh Profitabilitas, Keputusan Investasi Dan Keputusan Pendanaan Terhadap Nilai Perusahaan Farmasi Yang Terdaftar Di Bei Periode 20112014." Jurnal Berkala Ilmiah Efisiensi 16(4):465-74.

Rachmatus Solikhah, Desy, and Hariyati. 2019. "Pengaruh Pengungkapan Enterprise Risk Management Terhadap Nilai Perusahaan Dengan Profitabilitas Sebagai Variabel Mediasi." Jurnal Akuntansi AKUNESA 6(3):hlm. 5.

Rinnaya, Ista Yansi, Rita Andini, and Abrar Oemar. 2016. "Pengaruh Profitabilitas, Rasio Aktivitas, Keputusan Pendanaan, Keputusan Investasi Terhadap Nilai Perusahaan (Studi Empiris Pada Perusahaan Manufaktur Yang Terdaftar Di BEI Tahun 2010 2014).” 2(2).

Rolianah, Wiwik Saidatur, and Kholid Albar. 2019. Manajemen Risiko Bisnis Dalam Perspektif Islam. edited by Guepedia. Gresik: Guepedia.

Sanjaya, C. K., and N. Linawati. 2015. "Pengaruh Penerapan Enterprise Risk Management Dan Variabel Kontrol Terhadap Nilai Perusahaan Di Sektor Keuangan." Finesta 3(1):52-57.

Sari, Indah Oktavia. 2020. "Pengungkapan Enterprise Risk Management Sebagai Penentu Nilai Perusahaan Dengan Profitabilitas Sebagai Moderasi."

Soetedjo, Soegeng, Arina Manasikana, Sekretaris Badan, Pengawas Internal, Universitas Airlangga, Ketua Badan, Pengawas Internal, Universitas Airlangga, Ukuran Perusahaan, and Kepemilikan Manajerial. 2018. "Pengaruh Enterprise Risk
Management (ERM) Terhadap Nilai Perusahaan." 2(2):275-81.

Sutama, Dedi Rossidi, and Erna Lisa. 2018. "Pengaruh Leverage Dan Profitabilitas Terhadap Nilai Perusahaan (Studi Pada Perusahaan Sektor Manufaktur Food and Beverage Yang Terdaftar Di Bursa Efek Indonesia)." Jurnal Sains Manajemen \& Akuntansi X(1):hlm. 28.

Warno. 2014. "Kepatuhan Koperasi Di Kota Semarang Terhadap Standar Akuntansi Keuangan Entitas Tanpa Akuntan Publik (SAK ETAP) Tahun 2013." Ecomica V(1):hlm. 137.

Wijananti, SendyPutri. 2013. "Pengaruh Corporate Governance Dan Karakteristik Perusahaan Terhadap Pengungkapan Enterprise Risk Management Pada Perusahaan Non Keuangan Periode 2011-2013." 1-26. Wijaya, Bayu Irfandi, and I. B. Panji Sedana. 2015. "Pengaruh Profitabilitas Terhadap Nilai Perusahaan (Kebijakan Dividen Dan Kesempatan Investasi Sebagai Variabel Mediasi)." 4(12):hlm. 4479.

Wildan, Muhammad. 2019. "Kinerja Investasi Pada Sektor Manufaktur Turun Terus." 31 Oktober, hlm. 1.

Yuniata, Mei, Kharis Raharjo, and Abrar Oemar. 2016. "Pengaruh Kebijakan Deviden, Kebijakan Hutang Profitabilitas Dan Struktur Kepemilikan Terhadap Nilai Perusahaan Paada Perusahaan Manufaktur Yang Terdaftar Di Bursa Efek Indonesia Periode 2009-2014." Accounting 2(2):1-19.

Zuraida, Ida. 2019. "Pengaruh Struktur Modal, Ukuran Perusahaan, Profitabilitas Dan Kebijakan Dividen Terhadap Nilai Perusahaan." BALANCE Jurnal Akuntansi Dan Bisnis 4(1):529. doi: 10.32502/jab.v4i1.1828. 